\title{
Biocrusts inside and outside of Mimosa luisana resource islands as reservoirs of arbuscular mycorrhizal fungi in a Mexican semiarid ecosystem
}

\section{Biocostras dentro y fuera de islas de recursos de Mimosa luisana como reservorios de hongos micorrizógenos arbusculares en un ecosistema semiárido mexicano}

\author{
Sara Lucía Camargo-Ricalde, ${ }^{1}$ Noé Manuel Montaño, ${ }^{1}$ Susana A. Montaño-Arias, ${ }^{1}$ Claudia Janette De la \\ Rosa-Mera, ${ }^{2}$ Eduardo Chimal-Sánchez ${ }^{1,2}$

\footnotetext{
${ }^{1}$ Departamento de Biología, División de Ciencias Biológicas y de la Salud, Universidad Autónoma Metropolitana-Iztapalapa. San Rafael Atlixco No. 186, Col. Vicentina, Iztapalapa, C.P. 09340, Ciudad de México, México.

${ }^{2}$ Facultad de Estudios Superiores Zaragoza, Universidad Nacional Autónoma de México, Fuerte de Loreto esq. Batalla del 5 de mayo s/n, Ejercito de Oriente, Iztapalapa 09230, Ciudad de México, México.
}

\section{RESUMEN}

Antecedentes: Hongos micorrizógenos arbusculares (HMA) y biocostras (BC), están dentro y fuera de islas de recursos formadas por Mimosa luisana (M. luisana-IR), en el Valle de Tehuacán-Cuicatlán, Puebla-Oaxaca, México.

Objetivos: Determinar: 1) la presencia de HMA en las biocostras, 2) la abundancia y riqueza de HMA, y 3) el potencial de propagación de los HMA en $B C$ y suelo debajo de las $B C$, dentro (BC-IR, suelo-BC-IR) y fuera (BC-FIR, suelo-BC-FIR) de M. luisana-IR, y áreas abiertas (AA) en lluvias (septiembre-2011) y secas (mayo-2012).

Métodos: Los HMA se extrajeron de biocostras y suelo colectados dentro y fuera de M. luisana-IR y AA, en ambas estaciones. La abundancia de esporas y riqueza, así como la propagación potencial de los HMA se determinaron en el laboratorio e invernadero.

Resultados y Conclusiones: Las biocostras dentro y fuera de M. luisana-IR forman reservorios de esporas y riqueza de HMA (12 spp.), y actúan como "escudo" protector de los HMA, comparando con AA (5 spp.). La disponibilidad de agua regula las comunidades de HMA en biocostras y suelo. Las esporas de HMA en BC-IR y BC-FIR tienen un alto potencial de propagación y las BC-FIR amortiguan la pérdida de HMA formando inóculos micorrízicos en el suelo.

Palabras clave: costras biológicas del suelo, Glomeromycota, islas de fertilidad, leguminosas, Valle de Tehuacán-Cuicatlán

\section{ABSTRACT}

Background: Arbuscular mycorrhizal fungi (AMF) and biocrusts (BC), occur inside and outside Mimosa luisana resource islands (M. luisana-RI) at the Tehuacán-Cuicatlán Valley, Puebla-Oaxaca, Mexico.

Objectives: To determine: 1) Whether there are AMF within biocrusts, 2) The abundance and richness of AMF, and 3) The potential of AMF propagation in BC and soil below BC inside (BC-RI, soil-BC-RI) and outside (BC-ORI, soil-BC-ORI) M. luisana-RI, and open areas (OA), in the rainy (September 2011) and dry (May 2012) seasons.

Methods: AMF were extracted of biocrusts and soil samples collected inside and outside M. luisana-RI and OA, in both seasons. Spore abundance and species richness, as well as potential propagation of AMF were determined in laboratory and greenhouse.

Results and Conclusions: Biocrusts inside and outside M. luisana-RI form reservoirs of AMF spores and species richness (12 spp.), and act as "shields" protecting AMF compared with OA (5 spp.). Seasonal changes in the AMF composition within the biocrusts and the soil suggest that the availability of water drives AMF assemblages. The AM fungal spores in $\mathrm{BC}-\mathrm{RI}$ and $\mathrm{BC}-\mathrm{ORI}$ have a high potential of propagation; however, the BC-ORI by buffering the loss of AMF in soil-BCORI, they form mycorrhizal inocula within the soil.

Keywords: biological soil crusts, Glomeromycota, fertility islands, legumes, Tehuacán-Cuicatlán Valley

\section{ARTICLE HISTORY}

Received 14 August 2020 / Accepted 18 December 2020

Published on line: 8 April 2021
CORRESPONDING AUTHOR

\. Noé Manuel Montaño,nmma@xanum.uam.mx

ORCID: 0000-0001-5836-9837 


\section{INTRODUCTION}

Arbuscular mycorrhizal fungi (AMF; Phylum Glomeromycota) are ubiquitous and ancient microorganisms that establish mutualistic association with the roots of more than $85 \%$ of plants forming the arbuscular mycorrhizae (AM) (Smith and Read, 2008). This association is characterized by the presence of specific fungal structures called arbuscules within the root cortical tissue and extraradical mycelium forming spores and foraging resources into soil (Smith and Read, 2008); these fungi are critical for host plants grown at environmental stressful conditions, as it occurs in arid and semiarid ecosystems (Montesinos-Navarro et al., 2012).

AMF play an important role for vegetation at arid and semiarid ecosystems, since water stress and nutrient deficiencies are the most common constraints for plant growth (Tarafdar and Panwar, 2008). In these ecosystems, the AM is advantageous to mycorrhizal plants because the mycelium increases the root absorption area and is able to mobilize sparingly available soil nutrients, as phosphorus that is present as calcium phosphate, an insoluble chemical form, and its diffusion is further decreased by low soil moisture (Ezawa and Saito, 2018).

In Mexico, arid and semiarid ecosystems occupy about $60 \%$ of the surface of the country (Toledo and Ordoñez, 1998). In these environments, shrubs and trees mainly belonging to the Leguminosae family, contribute to soil fertility by protecting the understory vegetation and the soil against wind and water erosion, as well as by incorporating organic matter and nutrients into soil under their canopies, thus forming resource islands (RI) (Reynolds et al., 1999). Legumes as Acacia farnesiana (L.) Willd (Monroy et al., 2007), Prosopis laevigata (Humb et Bonpl ex Willd) (García-Sánchez et al., 2012), and several Mimosa species (Camargo-Ricalde and Dhillion, 2003; García-Sánchez et al., 2012; Montesinos-Navarro et al., 2012) may form Rl, that are not only rich in soil nutrients, but in mycorrhizal propagules. Within the semiarid valley of Tehuacán-Cuicatlán, Mexico, RI of Mimosa luisana Brandegee (M. luisana-RI), as well as other Mimosa species, serve as mycorrhizal reservoirs affecting AM fungal spore dynamics (Camargo-Ricalde and Dhillion, 2003; Camargo-Ricalde and Esperón-Rodríguez, 2005; Chimal-Sánchez et al., 2016).
Mimosa species, and a wide range of plants associated to them, are favored in biomass and nutrients through AMF in the RI (Camargo-Ricalde et al., 2003; Camargo-Ricalde et al., 2010a; Montesinos-Navarro et al., 2016; Sorbitrán et al., 2019).

Biocrusts composed of mosses, lichens, cyanobacteria, fungi, green algae and soil particles are present inside and outside M. luisana-RI (Rivera-Aguilar et al., 2006; Sandoval-Pérez et al., 2016). In arid and semiarid environments, biocrusts improve soil fertility by increasing nitrogen and carbon inputs, water infiltration, and providing habitat for soil fauna and microorganisms (Belnap and Lange, 2003; Sandoval-Pérez et al., 2016; Barrera Zublaga y Godinez Álvarez, 2018). However, the presence and dynamics of AMF in biocrusts are not very well known. For instance, Bates et al. (2010) and Porras-Alfaro et al. (2011) did not detect any AMF within biocrusts in different deserts of the world; in contrast, Hernández-Hernández et al. (2017) found AMF in biocrusts that could be linked to nutrient exchange between biocrusts and plants, alluding to the functional role of AMF in biocrusts as part of the 'fungal loop model' proposed by Collins et al. (2008) for arid ecosystems. Nevertheless, these contradictory studies show uncertainty on whether AMF are present in biocrusts at other arid and semiarid ecosystems.

It is not clear enough whether RI and biocrusts may act as AMF reservoirs, in arid and semiarid ecosystems; this knowledge is of critical importance, due to that these microenvironments could be promoting native mycorrhizal inocula, which could be useful for successful re-establishment of native plants in disturbed areas (Jasper et al., 1991; Chaudhary et al., 2019). In addition, both $\mathrm{RI}$ and biocrusts may be contributing to increase the inventory of AMF species in dry environments (Varela et al., 2019). However, whether or not, biocrusts host AMF assemblages inside and outside M. luisana-RI has never been investigated. Therefore, our objectives were to determine: 1) Whether there are AMF in biocrusts, 2) If present, the abundance and richness of $A M F$, and 3) The potential of propagation of $A M$ fungal spores associated to $B C$ and soil below $B C$, inside (BC-RI, soil-BC-RI) and outside (BC-ORI, soil$\mathrm{BC}-\mathrm{ORI})$ M. luisana-RI, and in open areas (OA, without plants and $\mathrm{BC}$ ), in the dry and rainy seasons, at the semiarid valley of Tehuacán-Cuicatlán, Puebla-Oaxaca, Mexico. 


\section{MATERIALS AND METHODS}

\section{Study site}

This study was performed in Zapotitlán Salinas, a semiarid region $\left(18^{\circ} 20^{\prime} \mathrm{N}, 97^{\circ} 28^{\prime} \mathrm{W}\right)$, which is located at the western side of the Biosphere Reserve of Tehuacán-Cuicatlán Valley, Puebla-Oaxaca, Mexico. Climate is semiarid, with an average annual temperature of 21 ${ }^{\circ} \mathrm{C}$, and an annual rainfall ranging from 400 to $600 \mathrm{~mm}$ (García, 2004). Rainfall is strongly seasonal, dry season extends from November to April, and approximately $74 \%$ of the rainfall occurs between May and October (Valiente-Banuet, 1991). Soils are sandy-clay-loams, mainly derived from sedimentary and metamorphic rocks, and classified as Calcisols (WRB, 2014). The main vegetation type is a xerophytic scrub dominated by the columnar cactus Neobuxbaumia tetetzo (F.A.C. Weber) Backeb., Agave spp. and different species belonging to the families Leguminosae and Asteraceae (Rzedows$\mathrm{ki}, 1978)$.

Within the Tehuacán-Cuicatlán Valley, 16 Mimosa species have been recorded, all of them thorny shrubs or small trees, from which seven species are endemic to Mexico and four species and one variety are endemic to the Valley (Martínez-Bernal and Grether, 2006). In addition, Mimosa species are either dominant or codominant in plant communities (Camargo-Ricalde et al., 2002); of these species, M. luisana is endemic to this Valley and it is the most abundant thorny shrub in Zapotitlán Salinas. This species is a nursery plant for $N$. tetetzo establishment (Valiente-Banuet and Ezcurra, 1991), form RI under its canopy (Camargo-Ricalde et al., 2010b), and it is frequently used by local people as firewood and in agroforestry practices (Dhillion and Camargo-Ricalde, 2005). Also, biocrusts are present on the soil inside M. luisana-Rl or outside these RI (Rivera-Aguilar et al., 2006; Sandoval-Pérez et al., 2016).

\section{Biocrusts and soil sampling}

The experimental design and soil sampling were based on Sandoval-Pérez et al. (2016). Five sites were chosen in relation to the presence of $M$. luisana-RI and the occurrence of biocrusts $(B C)$ in both inside (BC-RI) and outside (BC-ORI) M. luisana-RI. The sites were located at least one kilometer apart, and they belong to the same soil group: calcisols, and the vegetation type is xerophytic shrub ("matorral xerófilo"). In each site, one replicate plot of $20 \mathrm{~m} \times 50 \mathrm{~m}\left(1,000 \mathrm{~m}^{2}\right)$ was estab- lished, and six M. luisana plants of similar size (from 3 to $4 \mathrm{~m}$ in height and cover foliage) were randomly selected along each plot, where plants were at least $5 \mathrm{~m}$ of distance among each other. The similarities among the sites allowed minimizing the effect of the differences among the plots and maximizing that of the biocrusts on the AMF, based on a natural experimental design as defined by Diamond (1983). Thus, within M. luisana-RI, biocrusts (BC-RI) and soil below the BC (soil-BCRI) were collected from four different points around the trunk of each plant (microenvironments: BC-RI and soil$B C-R I)$; whereas, $B C$ and soil-BC outside M. luisana-RI (microenvironments: BC-ORI and soil-BC-ORI), as well as soil from open areas (microenvironment: OA) were also collected in six points selected randomly along the plot and separated up to $10 \mathrm{~m}$ of M. luisana-RI. The soil sampled in OA was considered as the control, and it was defined that an OA is any plot without both vegetation and biocrusts. The samples collected were manually mixed to form a composite biocrusts or soil sample from each microenvironment, per plot. In all cases, the biocrust and soil samples were collected from top 0-3 and 3-6 cm, respectively; where most of the biocrusts (Jimenez-Aguilar et al., 2009), and soil microbial activity are concentrated (Sandoval-Pérez et al., 2016). Litter was removed by hand prior to biocrusts and soil sampling. The same sampling procedure was done during the rainy (September 2011) and dry (May 2012) seasons. Biocrusts and soil samples were stored in black polypropylene bags and refrigerated at $10{ }^{\circ} \mathrm{C}$ in the laboratory.

\section{Spore abundance and species richness of AMF}

AM fungal spores were extracted from $100 \mathrm{~g}$ of biocrusts or soil by wet sieving method (Gerdemann and Nicolson, 1963) and centrifugation in $60 \%$ sucrose. Fungal spores were examined and counted (total abundance) with a stereoscopic microscope (Zoom 2000, Leica, Berlin); they were subsequently separated by morphotype based on their colour, shape and size, in order to make permanent preparations with polyvinyl alcohol-lactic acid-glycerol (PVLG) and PVLG plus Melzer's reagent $(1: 1, \mathrm{v} / \mathrm{v})$. The spores were observed in a Nomarski DIC Polarising Microscope (Olympus BX51, Tokyo) to analyse the structure of their walls as consistency, arrangement, reactivity to Melzer's reagent, ornamentations, germination shields and originating hyphae. Digital photographs 
of the spores were obtained with a digital camera (Toupcam UCMOS02000) and ToupTek View ${ }^{\circledR}$ scanning software vers. $x 64 \cdot 3.7 .1460$. The photographic records and permanent slides were deposited at the Laboratory of Legume Biosystematics, Department of Biology, Universidad Autónoma Metropolitana, Unidad Iztapalapa, Mexico City.

The taxonomic determination was made based on a comparison of the spore morphological features with the original descriptions of the AMF species, and those available at the International Culture Collection of (Vesicular) Arbuscular Mycorrhizal Fungi (Invam, 2018), the Glomeromycota Collection (http://www.zor.zut.edu.pl/ Glomeromycota/) and the Glomeromycota phylogeny database (http://amf-phylogeny.com/amphylo_taxonomy.html). AMF richness was determined as the number of species observed per microenvironment and season, while species composition was based on the AMF taxonomic identity (Moreno, 2001).

Propagation of arbuscular mycorrhizal inocula by pot-trap cultures

Pot-culture traps $(1 \mathrm{~kg})$ were prepared to propagate the AMF coming from biocrusts and soil samples collected in each microenvironment. These were prepared with $750 \mathrm{~g}$ of autoclaved ( $3 \mathrm{~d}$ per $1.5 \mathrm{~h} ; 120$ ${ }^{\circ} \mathrm{C}, 1.4 \mathrm{~kg} \mathrm{~cm}^{-2}$ ) substrate (gravel: sand: agrolite, 1:1:1 $\mathrm{v} / \mathrm{v}$ ), and $250 \mathrm{~g}$ of biocrust or soil samples, respectively. Brachiaria brizantha (Hochst. Ex A. Rich.) Stapf (Poaceae) was used as trap plant, because is one of the most cultivated grasses for fodder in tropical America (including the states of Puebla and Oaxaca, Mexico), harboring a great AMF species richness (Álvarez-Lopeztello et al., 2019). Pot-trap cultures were kept under greenhouse conditions for seven months, with temperatures ranging from $28{ }^{\circ} \mathrm{C}$ to $34^{\circ} \mathrm{C}$. Likewise, each pot-trap was watered every two weeks with 250 $\mathrm{mL}$ of a Long-Ashton Nutrient Solution, modified to supply $11 \mu \mathrm{g} \mathrm{P} \mathrm{mL}-1$; but these were always watered every third day with $200 \mathrm{~mL}$ of distilled water. To stimulate AM fungal spore production, the plants were trimmed every 30 days and watering was suspended 15 days before the plants were harvested. After seven months, all trap plants were harvested, and a subsample of roots was separated and processed to evaluate root mycorrhizal colonization by clearing and staining roots according to Phillips and Hayman (1970). The stained roots were set on slides (20 root fragments per slide), and observed under an optical microscope (Zeiss, Primo-Star, Germany), at 40X, to evaluate the presence of AM fungal structures (aseptate hyphae, arbuscules and vesicles). Likewise, AM fungal spores were extracted by the method of Gerdemann and Nicolson (1963) mentioned above, and abundance of AMF spores was also assessed after harvesting the trap plants, which allowed to explore the potential response of the AMF spores in each collected sample to be propagated. We expressed the propagation of AM fungal spores in percentage changes $(\% \Delta)$, with relation to initial (before pot culture trap) and final (after the harvest) abundance of AMF spores, which was calculated as: [(final abundance of AMF spores - initial abundance of AMF spores)/initial abundance of AMF spores)] $\times 100$.

\section{Statistical analysis}

Data were analyzed by repeated measures analysis of variance (RMANOVA), with one between-subject factor (microenvironments) and one within-factor (seasons), where sampling seasons were treated as repeated measures. This analysis was used because in the same experimental units (plots) the same variables were measured over two periods of time (dry and rainy seasons), so the plots were not independent (von Ende 2001). Likewise, since the samples used for the experiment of AMF spore propagation remained intact and replicated under the same design of the natural field experiment, the propagation data was also analyzed with RMANOVA. When the RMANOVA indicated some significant factor, mean comparisons were done with Tukey's HSD tests. Data were log- or arcosin- (\% mycorrhizal colonization) transformed to meet ANOVA assumptions (Sokal and Rohlf, 1995), but reported in their original scale of measurement. All analyses were performed with Statistica 6 software (StatSoft, 2000), and in all cases $P \leq 0.05$ was considered to be significant. Further, a non-metric multi-dimensional scaling (NMDS) was performed for comparison of AMF composition among microenvironments and between seasons. This procedure was made using the package Past version 3.25 (Hammer et al., 2001), the NMDS makes few assumptions about the distribution of data; in turn, it is an appropriate exploratory and ordering multivariate method when the data do not follow a linear model (Paliy and Shankar, 2016), as it happened with our data. 


\section{RESULTS}

Arbuscular mycorrhizal fungi spores were recorded in all microenvironments, especially in BC-RI and BC-ORI, as well in soil below biocrusts. When evaluating the AM fungal spore abundance before propagation, it was found an interaction between the tested factors (Table 1). This indicated that the AM fungal spore abundance was lower in OA than in the other microenvironments (Figure 1A), and it was higher in the dry season than in the rainy season only for BC-RI, BC-ORI, soil-BC-RI, soil-BC-ORI (Figure 1A). In contrast, after propagation, $B C-R I$ had the highest abundance of AM fungal spores, followed by BC-ORI, soil-BC-RI, and soil-BC-ORI, while the lowest was registered in the OA soil. It was consistent for both seasons in the case of soil, but for biocrusts more spore abundance was recorded in the samples collected in the rainy season than in the dry season (Table 1, Figure 1B).

After the propagation period, the percentage of change in the AM fungal spore abundance was affected by the microenvironment $\times$ season interaction, suggesting that the potential propagation of the AM fungal spores coming from a specific microenvironment is related to the season (Table 1). Thus, the AM fungal spores in $\mathrm{BC}-\mathrm{RI}$ and $\mathrm{BC}-\mathrm{ORI}$ were propagated only in the rainy season; though in the soil-BC-RI, AM fungal spores were propagated in both seasons; while in the soil-BC-ORI and OA soil, AM fungal spores did not propagate (Figure $1 \mathrm{C}$ ). In the dry and rainy seasons, where the propagation of AMF was positive, the abundance of fungal spores was one to four times higher than the spore abundance initially recorded in the field samples. Moreover, the highest level of spore propagation was recorded for BC inside and outside of Mimosa-RI, as well as in the soil under biocrusts inside Mimosa-RI (Figure 1C).

In $B$. brizantha, the average percentage of root colonization by AMF for all microenvironments, was 77 $\%$ (Figures 2 and $3 \mathrm{~A}-\mathrm{C}$ ). Colonization of the roots by aseptate hyphae did not vary among inocula (Table 1, Figure 2A), but the colonization by vesicles and arbuscules was influenced by the microenvironment $\times$ season interaction (Table 1). The percentage of vesicles was higher in the dry season than in the rainy season only when $B$. brizantha grew on the soil-BC-RI, soil-BC$\mathrm{ORI}$ and $\mathrm{OA}$ soil (Figure $2 \mathrm{~B}$ ). The percentage of arbuscules was the highest in BC-RI and BC-ORI; however, it was higher in the dry season than in the rainy season in BC-ORI, soil-BC-RI, soil-BC-ORI and OA soil (Figure 2C).

Fifteen AMF morphospecies, belonging to six genera: Acaulospora, Claroideoglomus, Funneliformis, Glomus, Rhizophagus, and Sclerocystis were identified (Table 2, Figure 3D-Q). Glomus was the genus better represented with five morphospecies, and Claroideoglomus lamellosum was present in all the microenvironments and seasons. In contrast, Acaulospora was not registered in the BC-RI. Biocrusts or soil samples collected in the rainy season registered higher AMF richness than those collected in the dry season, except for soil-BC-ORI and OA soil (Table 2). AMF richness

Table 1. F-ratios and significant levels of the repeated measures ANOVA to evaluate the propagation of arbuscular mycorrhizal inocula coming from different microenvironments (BC-RI, BC-ORI, soil-BC-IR, soil-BC-ORI, OA) ${ }^{+}$and seasons (dry and rainy) at semiarid valley of Tehuacán-Cuicatlán, Puebla-Oaxaca, Mexico

\begin{tabular}{|c|c|c|c|}
\hline \multirow{3}{*}{ Parameters } & \multicolumn{3}{|c|}{ Source of variation } \\
\hline & \multirow{2}{*}{$\begin{array}{c}\text { Between subject } \\
\text { Microenvironment (M) }\end{array}$} & \multicolumn{2}{|c|}{ Within subjects } \\
\hline & & Season (S) & $\mathrm{M} \times \mathrm{S}$ \\
\hline Before abundance of AM fungal spores & $14.85^{* * *}$ & $5.79^{*}$ & $14.65^{* *}$ \\
\hline After abundance of AM fungal spores & $10.1^{* *}$ & $4.2^{\text {ns }}$ & $9.87^{*}$ \\
\hline Change in abundance of AM fungal spores $(\Delta)$ & $6.15^{* * *+}$ & $0.93^{\text {ns }}$ & $21.63^{* *}$ \\
\hline AM colonization (hyphae) & $0.31^{\mathrm{ns}}$ & $0.13^{\text {ns }}$ & $1.69^{\mathrm{ns}}$ \\
\hline Vesicles & $0.51^{\mathrm{ns}}$ & $0.02^{\mathrm{ns}}$ & $10.52^{* *}$ \\
\hline Arbuscules & $0.41^{\mathrm{ns}}$ & $48.8^{n+x+x}$ & $14.6^{* *}$ \\
\hline
\end{tabular}

Note: $n s=$ not significant. ${ }^{*} p<0.05 ;{ }^{* \star} p<0.01 ;{ }^{\star \star \star} p<0.001$

+Abbreviations used in all tables and figures. BC-RI: Biocrusts inside M. luisana resource islands. BC-ORI: Biocrusts outside resource islands. soil-BC-IR: Soil below biocrusts inside M. luisana resource islands. soil-BC-ORI: Soil below biocrusts outside resource islands. OA soil: soil from open areas. 


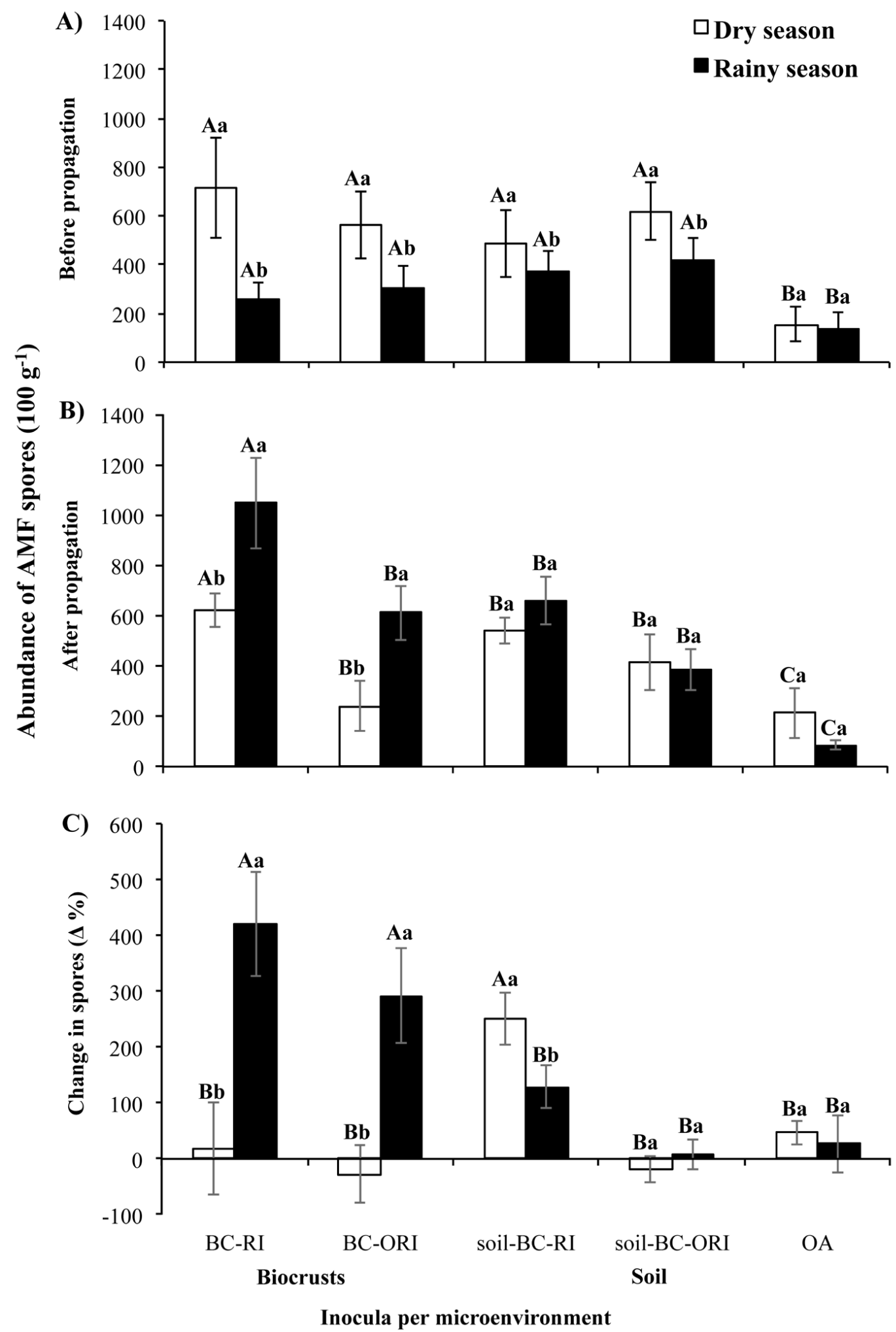

Figure 1. Seasonal means ( \pm standard error) of abundance of arbuscular mycorrhizal fungal spores in biocrusts (BC) inside and outside $M$. luisana resource islands (BC-RI and BC-ORI, respectively); soil below BC inside $M$. luisana resource islands (soil-BC-IR); soil below BC outside resource islands (soil-BC-ORI) and soil from open areas (OA soil) collected in the dry and rainy seasons, at semiarid valley of Tehuacán-Cuicatlán, Puebla-Oaxaca, Mexico. A: Before the propagation (initial spores). B: After the propagation with Brachiaria brizantha (final spores). C: Percentage of change $(\Delta \%)$ in fungal spores to detect the magnitude of AMF propagation. Bars with different uppercase and lowercase letters indicate significant differences $(p \leq 0.05)$ among microenvironments within a season and between seasons within a microenvironment, respectively. 


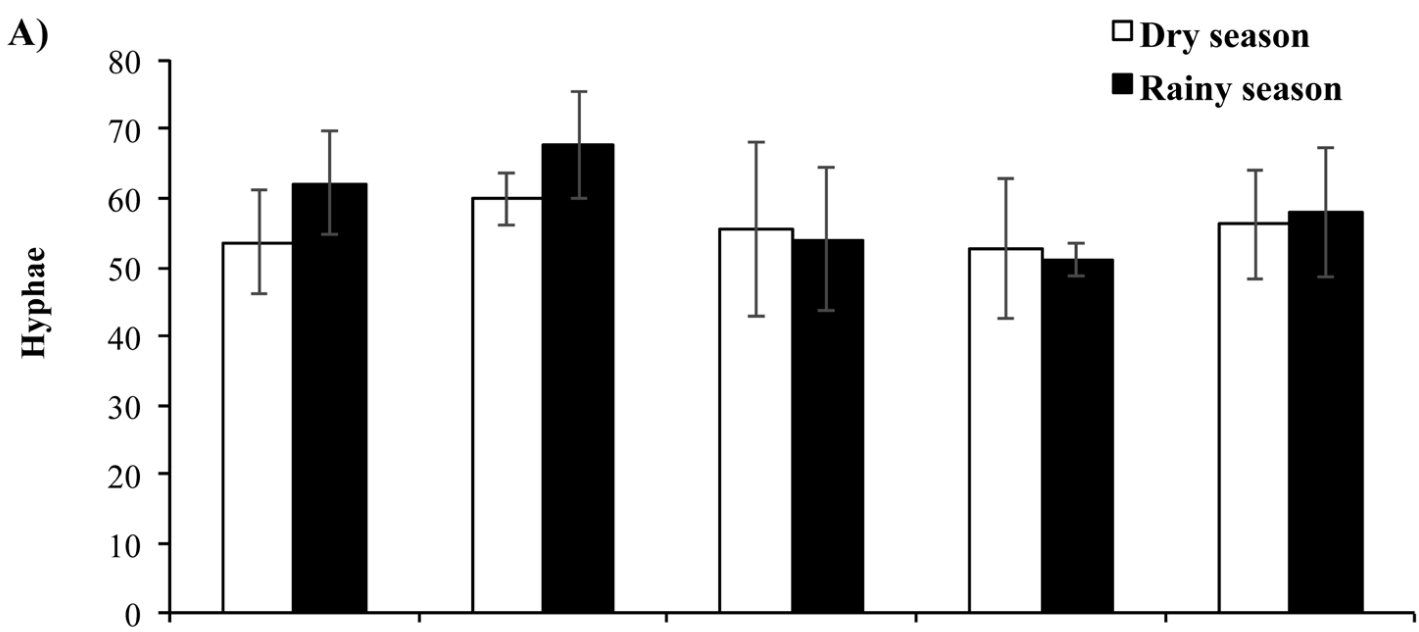

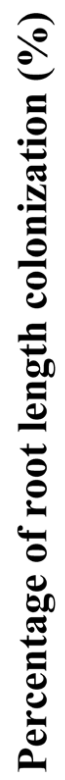

B)

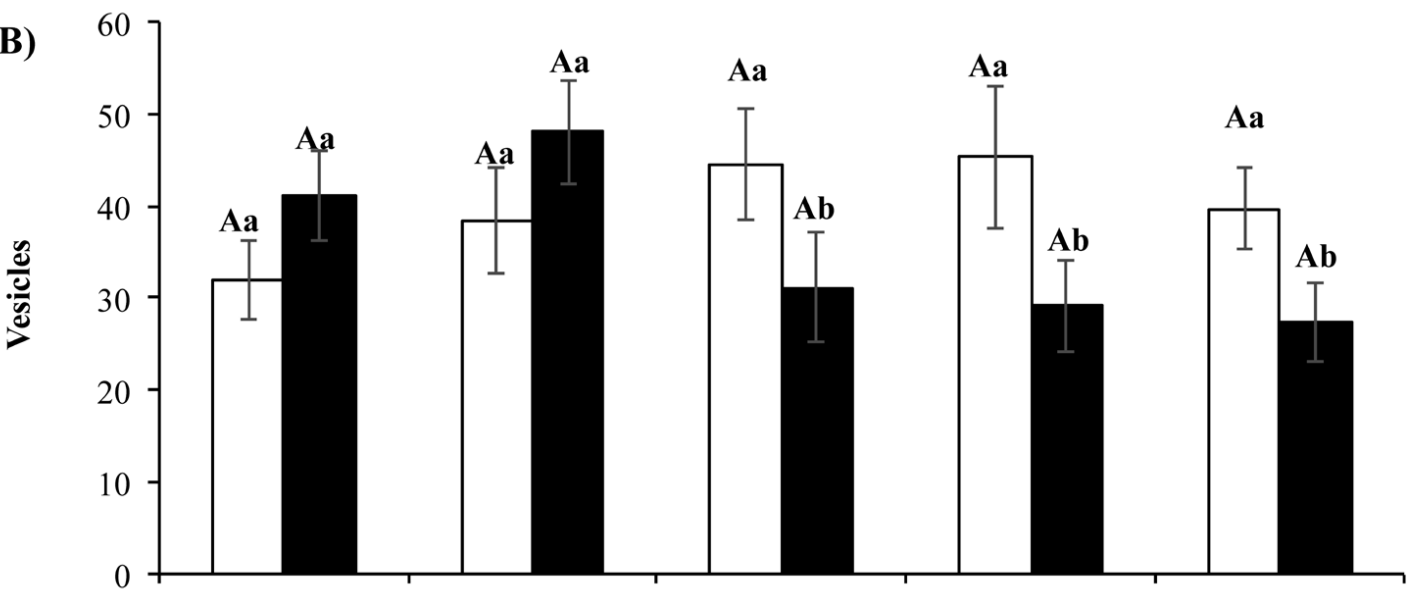

C)

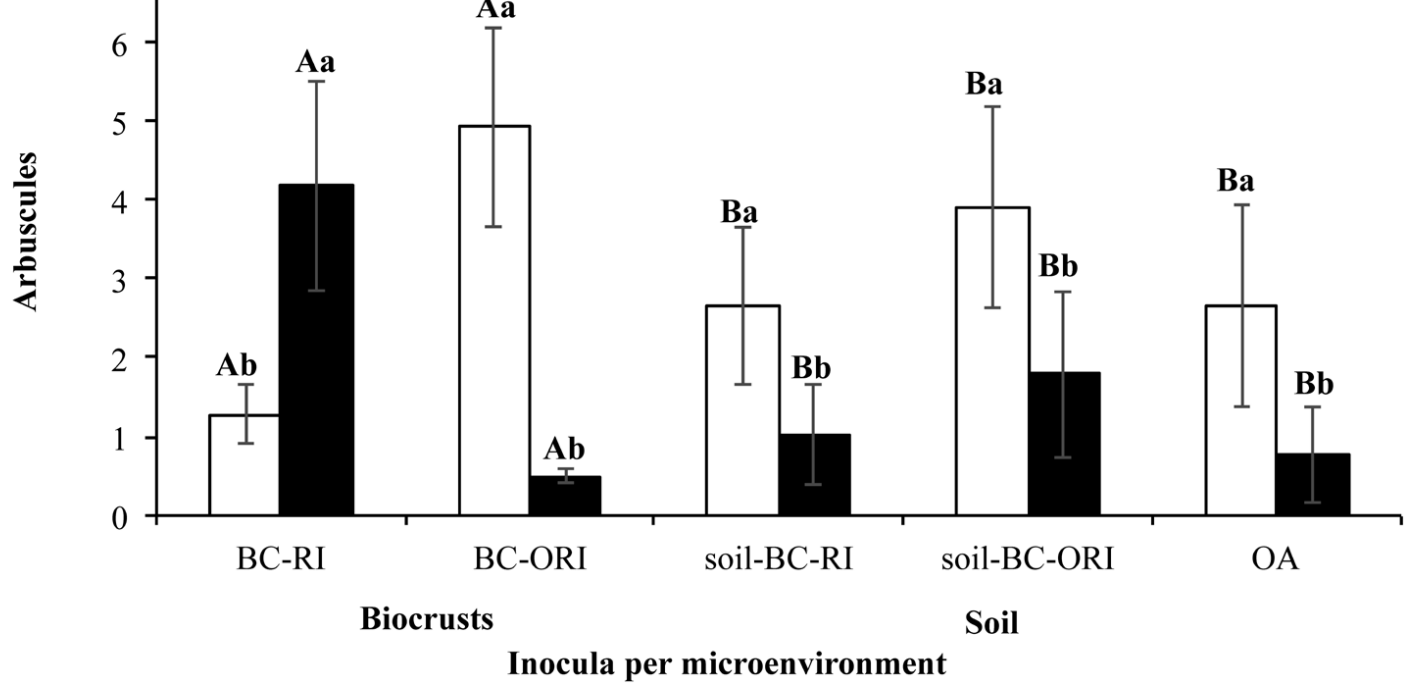

Figure 2. Percentage of mycorrhizal colonization ( \pm standard error) by aseptate hyphae, vesicles and arbuscules in the roots of Brachiaria brizantha after the propagation in pot-cultures of the inocula collected in biocrusts $(B C)$ inside and outside M. luisana resource islands (BC-RI and BC-ORI, respectively); soil below BC inside M. luisana resource islands (soil-BC-IR); soil below BC outside resource islands (soil-BC-ORI) and soil from open areas (OA soil) in the dry and rainy seasons, at semiarid valley of Tehuacán-Cuicatlán, Puebla-Oaxaca, Mexico. Bars with different uppercase and lowercase letters indicate significant differences $(p \leq 0.05)$ among microenvironments within a season, and between seasons within a microenvironment, respectively. 

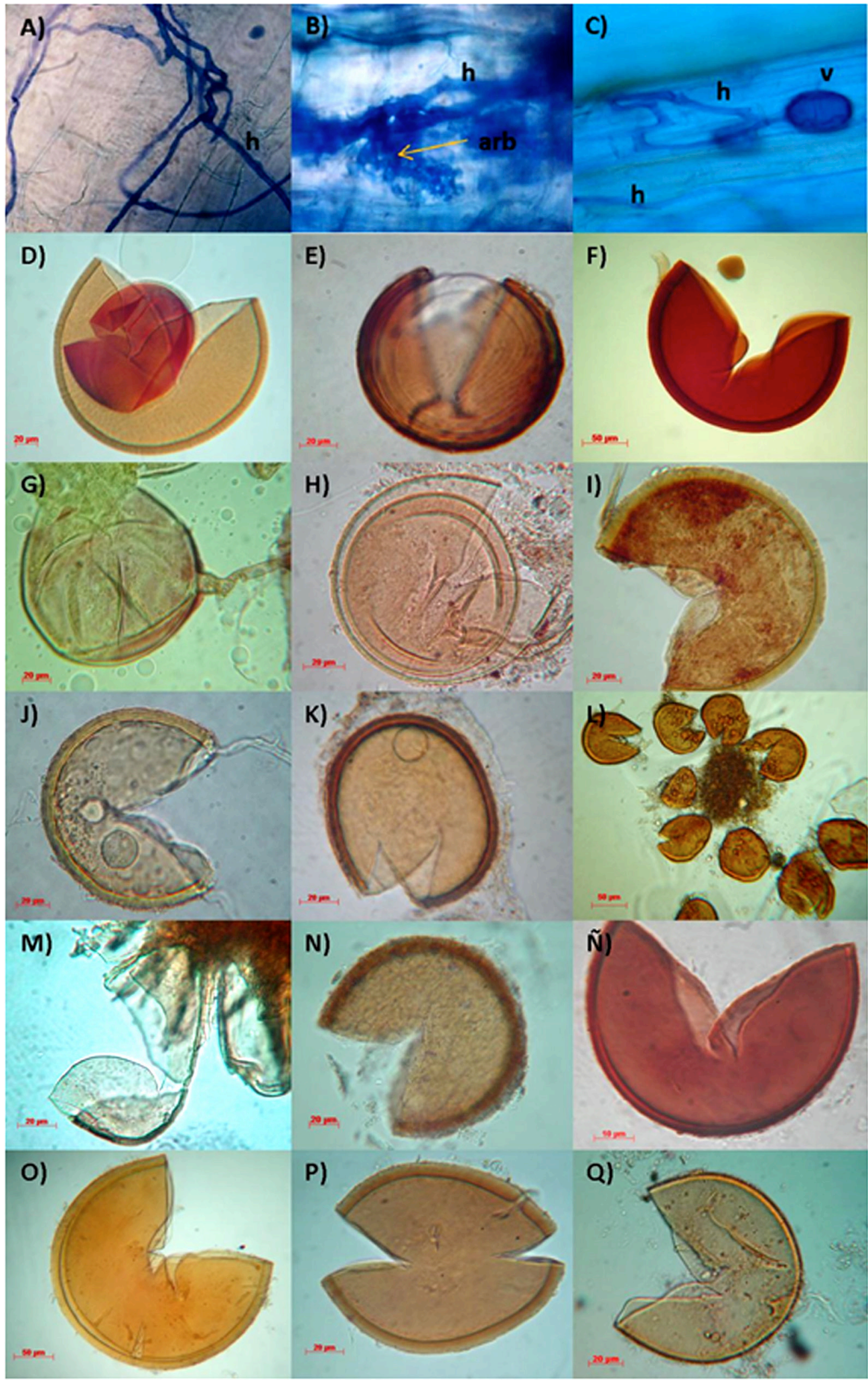

Figure 3. Arbuscular mycorrhizal fungi (AMF) and intercellular structures. A: aseptate hyphae. B: arbuscules. C: vesicles colonizing the roots of Brachiaria brizantha, which was used as a trap plant to propagate the AMF from biocrusts (BC) inside and outside M. luisana resource islands (BC-RI and BC-ORI, respectively); soil below BC inside $M$. luisana resource islands (soil-BC-IR); soil below BC outside resource islands (soilBC-ORI) and soil from open areas (OA soil) collected in the dry and rainy seasons, at semiarid valley of Tehuacán-Cuicatlán, Puebla-Oaxaca, Mexico. D: Acaulospora sp. E: Acaulospora sp.1. F: Funneliformis geosporum. G: F. mosseae. H: Rhizophagus aggregatum. I: Claroideoglomus aff. etunicatum. J: C. aff. lamellosum. K: C. aff. luteum. L: Sclerocystis rubiformis. M: S. sinuosa. N: Glomus sp. Ñ: Glomus sp.1. O: Glomus sp.2. P: Glomus sp.3. Q: Glomus sp.4. 
Table 2. Arbuscular mycorrhizal fungi (AMF) recorded in biocrusts (BC) inside and outside M. luisana resource islands (BC-RI and BC-ORI respectively); soil below BC inside $M$. luisana resource islands (soil-BC-IR); soil below BC outside resource islands (soil-BC-ORI) and soil from open areas (OA soil), in the dry and rainy seasons, at semiarid valley of Tehuacán-Cuicatlán, Puebla-Oaxaca, Mexico.

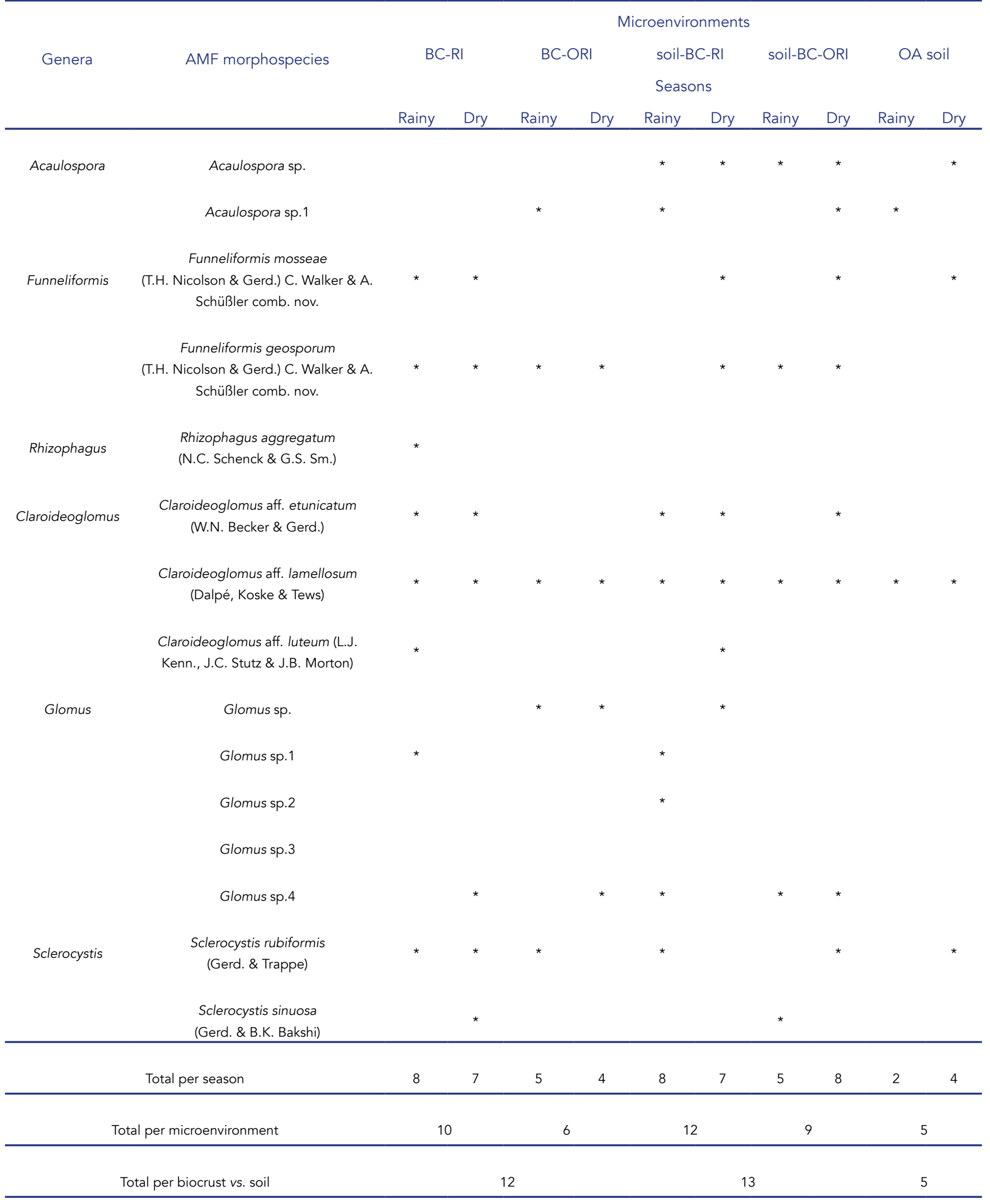




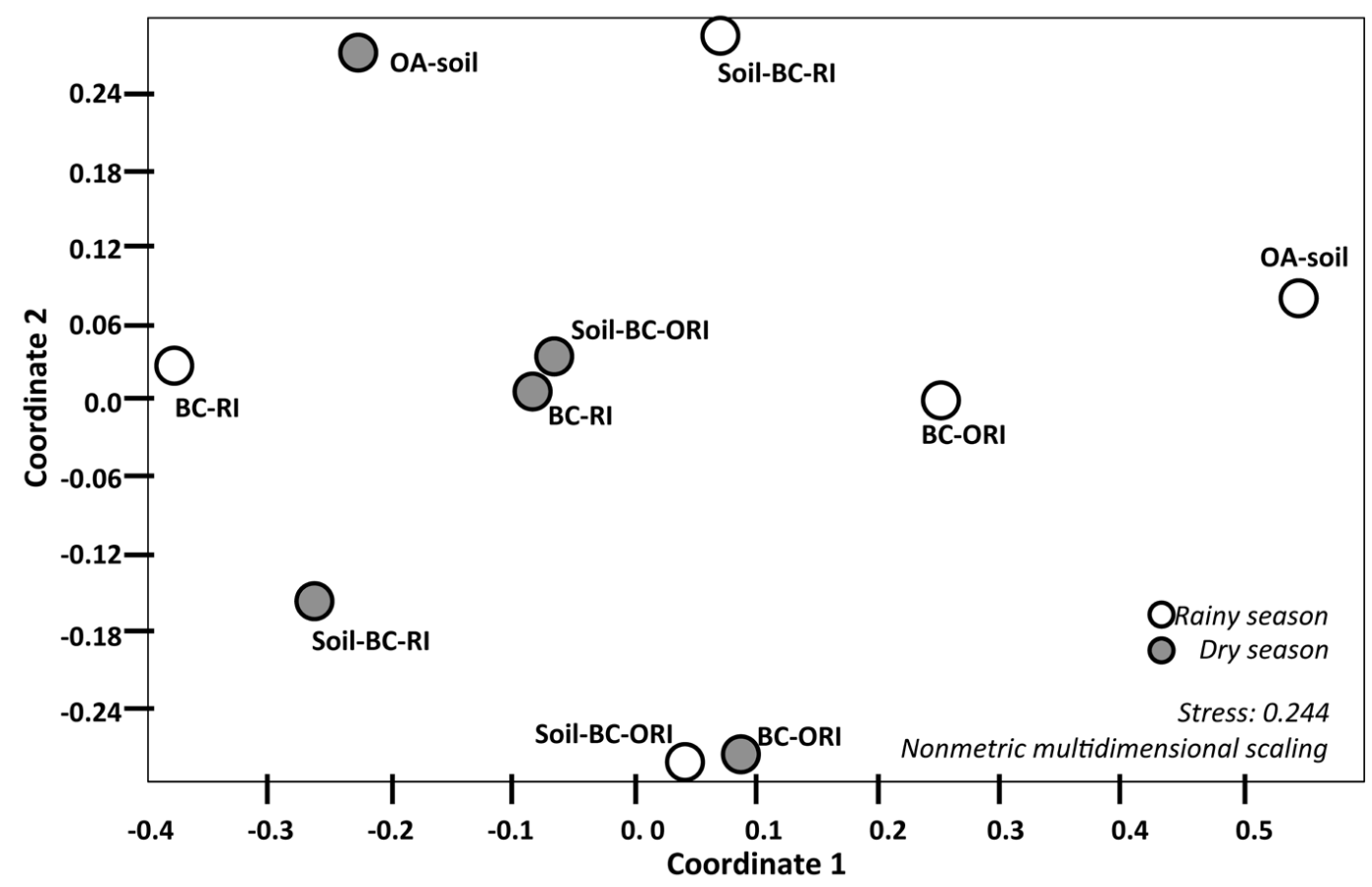

Figure 4. Non-metric multidimensional scaling (NMDS) of arbuscular mycorrhizal fungi composition in biocrusts (BC) inside and outside $M$. luisana resource islands (BC-RI and BC-ORI, respectively); soil below BC inside M. luisana resource islands (soil-BC-IR); soil below BC outside resource islands (soil-BC-ORI) and soil from open areas (OA soil) collected in the dry and rainy seasons, at semiarid valley of the Tehuacán-Cuicatlán, Puebla-Oaxaca, Mexico.

was higher in the BC-RI and soil-BC-RI than in BC-ORI, soil-BC-ORI and OA soil, the latter also showed the lowest species richness. In total, 12, 13, and 5 AMF morphospecies were recorded in $\mathrm{BC}$, soil-BC and $\mathrm{OA}$ soil, respectively (Table 2). However, after the propagation period, no AMF, others than those recorded in the field samples, were registered. Thus, AMF composition changed with rainfall seasonality, where $\mathrm{BC}-\mathrm{RI}$ and soilBC-ORI had wide dissimilarity in their AMF communities between them and respect to the other microenvironments in the rainy season (Figure 4).

\section{DISCUSSION}

The overall results showed that the $\mathrm{BC}-\mathrm{RI}$ and $\mathrm{BC}$ ORI, as well as soil-BC-RI and soil-BC-ORI, favour the abundance and richness of AMF in comparison to OA. Erosive and biotic factors could be promoting the dispersion of $A M$ fungal spores from surrounding plants towards the RI formed by legumes, as M. luisana (Camargo-Ricalde and Dhillion, 2003). Moreover, herbaceous plants and cacti inhabiting M. luisana-RI (Valiente-Banuet and Ezcurra, 1991; Camargo-Ricalde et al., 2003; Montesinos-Navarro et al., 2012; Sorti- brán et al., 2019) may promote spores abundance and species richness of AMF, since they are mycotrophic hosts (Camargo-Ricalde et al., 2003). Thus, Mimosa-RI have been considered as AM fungal spore reservoirs (Camargo-Ricalde and Dhillion, 2003; Camargo-Ricalde and Esperón-Rodríguez, 2005). Once inside the $M$. luisana-RI, AM fungal spores may also be trapped due to: i) Its association with the plants growing under the canopy of M. luisana (Camargo-Ricalde et al., 2003); ii) The microtopography of the biocrusts has more capture spore power than disturbed soil (Belnap and Lange, 2003; Jimenez-Aguilar et al., 2009); and iii) Mosses could be associated with AMF sporulating within the biocrusts (Zhang and Guo, 2007). Studies on Mimosa spp. and/or biocrusts at the Tehuacán-Cuicatlán Valley have not reported the dynamic of AM fungal spores (Rivera-Aguilar et al., 2006; Sandoval-Pérez et al., 2016); likewise Camargo-Ricalde and Dhillion (2003) and Camargo-Ricalde and Esperón-Rodríguez (2005) only reported the effect of the rainfall seasonality on AMF abundance in M. luisana-RI without considering the biocrusts; so our study suggests that biocrusts and $M$ luisana-RI, jointly, favour AMF communities at this semiarid ecosystem. 
The abundance and species richness of AMF in BC-ORI and soil-BC-ORI may also be attributed to the presence of polysaccharides produced by the biocrusts, which are able to capture soil particles and dust that, probably, are transporting fungal spores from near or even distant vegetation patches (Belnap and Lange, 2003; Guo et al., 2007). In addition, AM fungal propagules are able to disperse by wind and animal vectors, and could be deposited onto biocrusts (Chaudhary et al., 2019). In turn, the BC-ORI could act as a "shield" that reduces soil erosion and loss of $A M$ fungal spores. Likewise, the mosses of BC-RI and BC-ORI (Sandoval-Pérez et al., 2016) could be establishing symbiosis with AMF as explained before. For instance, Zhang and Guo (2007) reported 15 AMF belonging to Glomus, Acaulospora, Gigaspora, and Paraglomus genera, as well as AM structures occurring in moss crusts. Also, mycorrhizal mycelia and roots may be linking biocrusts outside to biocrusts inside $M$. luisana-RI or vegetation patches according to the "fungal loop model" (Collins et al., 2008), because AMF explore biocrusts to mine nutrients (Hawkes, 2003), that results in the presence of AMF in the biocrusts; however, it is still necessary to quantify the soil mycorrhizal mycelium to test this hypothesis. Nevertheless, these findings support the fact that biocrusts, inside and outside M. luisana-RI, may be considered as AMF reservoirs at the Tehuacán-Cuicatlán Valley, as it has been suggested for other deserts (Hernández and Hernández et al., 2017). Even though, our findings contradict those reported by Bates et al. (2010) and Porras-Alfaro et al. (2011), who did not detect AMF in biocrusts at the Colorado Plateau, Chihuahuan, $\mathrm{Ne}-$ gev, Wyoming and Sevilleta New Mexico deserts.

As it has previously been shown in Mimosa spp. of the Tehuacán-Cuicatlán Valley, AMF had a seasonal sporulation pattern (Camargo-Ricalde and Esperón-Rodríguez, 2005), which may be attributed to differences in AMF composition recorded between the dry and rainy seasons, since sporulation of AMF species varies according to soil moisture, as a response to host phenology and their colonization strategies (Hart and Reader, 2002). Besides, a high diversity of plant species within Mimosoideae-RI (Perroni-Ventura et al., 2006), favour the availability of hosts for AMF, decreasing the abundance of AM fungal spores in the rainy season compared to the dry season (de Souza et al., 2016), where, in the latter, AM fungal spores are stored and protected by the biocrusts, even outside M. luisana-RI.
Not all the biocrusts or the soil samples allowed propagation of $A M$ fungal spores using $B$. brizantha as a trap plant, this suggests that propagation is related to the AMF species and the host plant species involved (Selvakumar et al., 2016). Thus, spores propagation in BC-RI, BC-ORI, and soil-BC-RI (rainy season), and in soil-BC-RI (dry season), may be attributed to differences in AMF species richness and composition, compared to the dry season and to the other microenvironments, since in this study, host plant was not a variant. The lack of propagation of AM fungal spores in samples from soil-BC-ORI and OA may also be due to low sporulation rate of determined AMF species, as it has been reported in desertic ecosystems (Stutz and Morton, 1996). Even though AM fungal spores were not propagated in all the samples analysed, the levels of mycorrhizal colonization in $B$. brizantha roots were higher than those reported for biocrusts $(5.9 \%$ and 8-39\%, Chaudhary et al., 2019; Havrilla et al., 2020, respectively), and similar across all the inocula tested. This also suggests that the AM fungal spores were not always the main inoculum source in all the samples, because the soil may contain other mycorrhizal propagules, as mycelium and colonized roots (Jasper et al., 1991; Addy et al., 1997). However, it highlights that $B$. brizantha, grown in OA inoculum, with the lowest AM fungal spore abundance and species richness, showed similar root colonization than in the other inocula. This suggests that AMF from OA might have similar rates of spore germination, mycorrhization potential, root penetration and fungal growth than those inocula coming from microenvironments with more nutrients. Thus, all microenvironments could be promoting inocula with other mycorrhizal propagules more important than the fungal spores alone.

Those inocula of biocrusts collected in the rainy season promoted the formation of vesicles and arbuscules in the roots of $B$. brizantha, particularly when it was grown in BC-RI, which may be indicating that AMF species were more efficient for nutrient exchange; while a high level of vesicles and arbuscules colonizing $B$. brizantha roots, in the soil-BC-ORI and soil below biocrusts or $O A$, in the dry season, agree with observations done by Allen (1983), who registered an increase in the colonization by vesicles in desert plants during the dry season.

The record of 15 AMF morphotypes was similar to that reported for the arid region from the Namibian desert 
(Uhlmann et al., 2006) but very low in comparison to the semiarid region of Namibia, as well as the Chihuahuan and Sonoran Deserts and the Tehuacán-Cuicatlán VaIley, where 23 to 44 AMF species have been registered (Uhlmann et al., 2004; Pezzani et al., 2006; Bashan et al., 2007; Chimal-Sánchez, 2015). Nevertheless, it is possible that other AMF may be present in our study site, because up to 163 DNA sequences have already been identified for the Glomus group $A$, showing a complex mutualistic network with $M$. luisana (Montesinos-Navarro et al., 2012) and new records of AMF have been detected in Mimosa spp. (Chimal-Sánchez et al., 2016), but further studies are required. However, this study is the first to detect morphologically AMF into biocrusts at a Mexican semiarid ecosystem, so it is not possible to compare directly with other studies, although it does confirm the presence of AMF in biocrusts, as it occurs in other semiarid ecosystems (Hernández-Hernández et al., 2017).

\section{CONCLUSIONS}

To our best knowledge, this is the first study, within a Mexican semiarid ecosystem (Tehuacán-Cuicatlán Valley), that provides a set of data supporting the fact that biocrusts, inside and outside M. luisana-RI, form reservoirs of AMF spores and species, and that these biocrusts act as "shields" that protect the AMF in the soil below them, in comparison to OA soil. Seasonal changes in the composition of AMF communities, associated to biocrusts and soil, suggesting that water availability (rainy season) may also be a possible driver of AMF assemblages in these microenvironments, within this semiarid ecosystem. Likewise, the AM fungal spores from $\mathrm{BC}-\mathrm{RI}$ and $\mathrm{BC}-\mathrm{ORI}$ have a high potential of propagation; however, the BC-ORI, by buffering the loss of AMF in soil, also promote mycorrhizal inocula into soil.

\section{ACKNOWLEDGMENTS}

We thank Jessica Miguel de la Cruz for her assistance during the field work, as well as to Andrea Gutierrez Ponce, Alejandra Velázquez Romo, Genaro Montaño Arias, Rosalva García-Sánchez, and Susana Padrón Hernández for their technical support in the greenhouse or laboratory work. We thank Jesús Pérez-Moreno and Alejandro Alarcón for useful and constructive comments on an early draft of this paper. The authors are grateful to Laura Hernández Cuevas and Lucía Varela for a first identification of the fungal spores. Finally, we also thank the critical comments of two anonymous reviewers, who helped us to improve the manuscript for publication.

\section{REFERENCES}

Addy, H.D., M.H. Miller, R.L. Peterson, 1997. Infectivity of the propagules associated with extraradical mycelia of two AM fungi following winter freezing. New Phytologist 135: 745-753. Doi: 10.1046/j.1469-8137.1997.00707.x

Allen, M.F., 1983. Formation of vesicular-arbuscular mycorrhizae in Atriplex gardneri (Chenopodiaceae): seasonal response in a cold desert. Mycologia 75: 773-776. Doi: 10.1080/00275514.1983.12023753

Álvarez-Lopeztello, J., L. Hernández-Cuevas, R.F. del Castillo RF, C. Robles, 2019. Diversity of arbuscular mycorrhizal fungi associated with Brachiaria brizantha pastures in lowlands of Oaxaca, Mexico. Grassland Sciences 65(3): 197-201. Doi: 10.1111/ grs. 12224

Bashan, Y., T. Khaosaad, B.G. Salazar, J.A. Ocampo, A. Wiemken, F. Oehl, H. Vierheilig, 2007. Mycorrhizal characterization of the boojun tree, Fouquieria columnaris, an endemic ancient tree from the Baja California Peninsula, Mexico. Trees Structure and Function 21: 329-335. Doi: 10.1007/s00468-007-0126-2

Bates, S.T., F. García-Pichel, T.H. Nash III, 2010. Fungal components of biological soil crusts: insights from culture-dependent and culture-independent studies. In: Nash III, T.N., L. Geiser, B. McCune, D. Triebel, A.M. Tomescu, W. Sanders (eds.), Biology of Lichens - symbiosis, ecology, environmental monitoring, systematics, cyber applications. Bibliotheca Lichenologica 105. J. Cramer der Gebrüder Borntraeger Verlagsbuchhandlung, Stuttgart. Pp. 197-210.

Barrera Zublaga, E., H. Godínez Álvarez, 2018. Infiltración en biocostras en una región semiárida del centro de México. Terra Latinoamericana 36: 337-343. Doi: 10.28940/terra.v36i4.335

Belnap, J., O.L. Lange, 2003. Biological soil crust: Structure, function, and management. Springer-Verlag, Berlin.

Camargo-Ricalde, S.L., S.S. Dhillion, R. Grether, 2002. Community structure of endemic Mimosa species and environmental heterogeneity in a semi-arid Mexican Valley. Journal of Vegetation Sciences 13: 697-704. Doi: 10.1111/j.1654-1103.2002.tb02097.x

Camargo-Ricalde, S.L., S.S. Dhillion, 2003. Endemic Mimosa species can serve as mycorrhizal "resource islands" within semiarid communities of the Tehuacán-Cuicatlán Valley, Mexico. Mycorrhiza 13: 129-136. Doi: 10.1007/s00572-002-0206-5

Camargo-Ricalde, S.L., S.S. Dhillion, C. Jiménez-González, 2003. Mycorrhizal perennials of the "matorral xerófilo" and the "selva baja caducifolia" communities in the semiarid Tehuacán-Cuicatlán Valley, Mexico. Mycorrhiza 13: 77-83. Doi: 10.1007/s00572002-0203-8

Camargo-Ricalde, S.L., M. Esperón-Rodríguez, 2005. Efecto de la heterogeneidad espacial y estacional del suelo sobre la abundancia de esporas de hongos micorrizógenos arbusculares en el valle semiárido de Tehuacán-Cuicatlán, México. Revista de Biología Tropical 53: 339-352. Doi: 10.15517/RBT.V53I3-4.14594

Camargo-Ricalde, S.L., N.M. Montaño, I. Reyes-Jaramillo, C. Jiménez-González, S.S. Dhillion, 2010a. Effect of mycorrhizae on seedlings of six endemic Mimosa L. species (Leguminosae-Mimosoideae) from the semi-arid Tehuacán-Cuicatlán Valley, Mexico. Tress 24: 67-78. Doi: 10.1007/s00468-009-0379-z 
Camargo-Ricalde, S.L., I. Reyes-Jaramillo, N.M. Montaño, 2010b. Forestry insularity effect of four Mimosa L. species (Leguminosae-Mimosoideae) on soil nutrients of a Mexican semiarid ecosystem. Agroforestry Systems 80: 385-397. Doi: 10.1007/ s10457-010-9330-y

Chaudhary, V.B., K. Akland, N.C. Johnson, M.A. Bowker, 2019. Do soil inoculants accelerate dryland restoration? A simultaneous assessment of biocrusts and mycorrhizal fungi. Restoration Ecology 28: S115-S126.. Doi: 10.1111/rec.13088

Chimal-Sánchez, E., 2015. Influencia de cuatro especies del género Mimosa L. (Leguminosae) en la diversidad y potencial de inóculo de hongos micorrizógenos arbusculares en un ecosistema semiárido de México. Tesis de Maestría, Universidad Autónoma Metropolitana - Iztapalapa, Mexico.

Chimal-Sánchez, E., N.M. Montaño, S.L. Camargo-Ricalde, R. García-Sánchez, L.V. Hernández-Cuevas, 2016. Nuevos registros de hongos micorrizógenos arbusculares para México. Revista Mexicana de Biodiversidad 20: 242-247. Doi: 10.1016/j. rmb.2016.01.024

Collins, S.L., R.L. Sinsabaugh, Ch. Crenshaw, L. Green, A. Porras-Alfaro, M. Stursova, L.H. Zeglin, 2008. Pulse dynamics and microbial processes in aridland ecosystems. Journal of Ecology 96: 413-420. Doi: 10.1111/j.1365-2745.2008.01362.x

de Souza, T.A., S. Rodriguez-Echeverría, L.A. de Andrade, H. Freitas, 2016. Arbuscular mycorrhizal fungi in Mimosa tenuiflora (Willd.) Poir from Brazilian semi-arid. Brazilian Journal of Microbiology 47: 359-366. Doi:10.1016/j.bjm.2016.01.023.

Diamond, J., 1983. Laboratory, field and natural experiments. Nature 304: 586-587. Doi: 10.1038/304586a0

Dhillion, S.S., S.L. Camargo-Ricalde, 2005. The cultural and ecological roles of Mimosa species in the Tehuacán-Cuicatlán Valley, Mexico. Economic Botany 59: 390-394. Doi: 10.1663/0013-0001(2005)059[0390:NOEP]2.0.CO;2

Ezawa, T., K. Saito, 2018. How do arbuscular mycorrhizal fungi handle phosphate? New insight into fine-tuning of phosphate metabolism. New Phytologist 220: 1116-1121. Doi: 10.1111/nph.15187

García, E., 2004. Modificaciones al sistema de clasificación climática de Köeppen. $5^{a}$ ed. Serie Libros 6. Instituto de Geografía, UNAM, México, D.F.

García-Sánchez, R., S.L. Camargo-Ricalde, E. García-Moya, M. Luna-Cavazos, A. Romero-Manzanares, N.M. Montaño, 2012. Prosopis laevigata and Mimosa biuncifera, jointly influence plant diversity and soil fertility in a Mexican semiarid ecosystem. Revista de Biología Tropical 60: 87-103. Doi: 10.15517/rbt.v60i1.2365

Gerdemann, J.W., T.H. Nicolson, 1963. Spores of mycorrhizal Endogone species extracted from soil by wet sieving and decanting. Transactions of the British Mycological Society 46: 235-244. Doi: 10.1016/S0007-1536(63)80079-0

Guo, Y., H. Zhao, X. Zuo, S. Drake, X. Zhao, 2007. Biological soil crust development and its topsoil properties in the process of dune stabilization, Inner Mongolia, China. Environmental Geology 54: 653-662. Doi: 10.1007/s00254-007-1130-y

Hammer, O., T.A. Harper, P.D. Ryan, 2001. PAST: Paleontological statistics software package for education and data analysis. Paleontología-e 4: 1-9.
Hart, M.M., R.J. Reader, 2002. Taxonomic basis for variation in the colonization strategy of arbuscular mycorrhizal fungi. New Phytologist 153: 335-344. Doi: 10.1046/j.0028-646X.2001.00312.x

Hawkes, C.V., 2003. Nitrogen cycling mediated by biological soil crusts and arbuscular mycorrhizal fungi. Ecology 84: 1553-1562. Doi: 10.1890/0012-9658(2003)084[1553:NCMBBS]2.0.CO;2

Hernández-Hernández, R.M., A. Roldán, F. Caravaca, G. Rodriguez-Caballero, M.P. Torres, F.T. Maestre, M.M. Alguacil, 2017. Arbuscular mycorrhizal fungal assemblages in biological crusts from a Neotropical savanna are not related to the dominant perennial Trachypogon. Sciences of the Total Environment 575: 1203-1210. Doi: 10.1016/j.scitotenv.2016.09.190

Havrilla, C., A.D. Leslie, J.L. Di Biase, N.N. Barger, 2020. Biocrusts are associated with increased plant biomass and nutrition at seedling independently of root-associated fungal colonization. Plant and Soil 446: 331-342. Doi: 10.1007/s11104-019-04306-4

Invam (International Culture Collection of (Vesicular) Arbuscular Mycorrhizal Fungi), 2018. Species descriptions from reference cultures. West Virginia University, Morgantown.

Jasper, D.A., L.K. Abbot, A.D. Robson, 1991. The effect of soil disturbance on vesicular-arbuscular mycorrhizal fungi in soils from different vegetation types. New Phytologist 118: 471-476. Doi: 10.1111/j.1469-8137.1991.tb00029.x

Jiménez-Aguilar, A., E. Huber-Sannwald, J. Belnap, D.R. Smart, J.T. Arredondo, 2009. Biological soil crusts exhibit a dynamic response to seasonal rain and release from grazing with implications for soil stability. Journal of Arid Environment 73: 11581169. Doi: 10.1016/j.jaridenv.2009.05.009

Martínez-Bernal, A., R. Grether, 2006. Mimosa. In: Novelo, A., R. Medina-Lemus (eds.), Flora del Valle de Tehuacán-Cuicatlán. Fascículo 44. Instituto de Biología, Universidad Nacional Autónoma de México, México, D.F. Pp. 42-99.

Monroy, A., J. Estévez, R. García-Sánchez, R. Ríos-Gómez, 2007. Establecimiento de plántulas mediante el uso de micorrizas y de islas de recursos en un matorral xerófilo deteriorado. Boletín de la Sociedad Botánica de México 80: 49-57. Doi: 10.17129/ botsci. 1756

Montesinos-Navarro, A., J.G. Segarra-Moragues, A. Valiente-Banuet, M. Verdú, 2012. The network structure of plant-arbuscular mycorrhizal fungi. New Phytologist 194: 536-547. Doi: 10.1111/j.1469-8137.2011.04045.x

Montesinos-Navarro, A., M. Verdú, J.I. Querejeta, L. Sorbitán, A. Valiente-Banuet, 2016. Soil fungi promote nitrogen transfer among plants involved in long-lasting facilitative interactions. Perspectives in Plant Ecology, Evolution and Systematics 18: 45-51. Doi: 10.1016/j.ppees.2016.01.004

Moreno, E.C., 2001. Manual de métodos para medir la biodiversidad. Textos universitarios: Universidad Veracruzana, Xalapa.

Paliy, O., V. Shankar, 2016. Application of multivariate statistical techniques in microbial ecology. Molecular Ecology 25: 1032-1057. Doi: $10.1111 / \mathrm{mec} .13536$

Perroni-Ventura, Y., C. Montaña, F. García-Oliva, 2006. Relationship between soil nutrient availability and plant species richness in a tropical semi-arid environment. Journal of Vegetation Sciences 17: 719-728. Doi: 10.1658/11009233(2006)17[719:RBSNAA]2.0. $\mathrm{CO} ; 2$ 
Pezzani, F., C. Montaña, R. Guevara, 2006. Associations between arbuscular mycorrhizal fungi and grasses in the successional context of the two-phase mosaic in the Chihuahuan Desert. Mycorrhiza 16: 285-295. Doi: 10.1007/s00572-006-0044-y

Philliips, J.M., D.S. Hayman, 1970. Improved procedures for clearing roots and staining parasitic and vesicular-arbuscular mycorrhizal fungi for rapid assessment of infection. Transactions of the British Mycological Society 55: 158-161. Doi: 10.1016/S00071536(70)80110-3

Porras-Alfaro, A., J. Herrera, D.O. Natvig, K. Lipinski, R.L. Sinsabaugh, 2011. Diversity and distribution of soil fungal communities in a semiarid grassland. Mycologia 103(1): 10-21. Doi: 10.3852/09-297

Reynolds, J.F., R.A. Virginia, P.R. Kemp, A.G. De Soyza, D.C. Tremmel, 1999. Impact of drought on desert shrubs: effects of seasonality and degree of resource island development. Ecological Monographs 69: 69-106. Doi: 10.1890/00129615(1999)069[0069:IODODS]2.0.CO;2

Rivera-Aguilar, V., G.B. Montejano, S. Rodríguez-Zaragoza, A. Durán-Díaz, 2006. Distribution and composition of cyanobacteria, mosses and lichens of the biological soil crusts of the Tehuacán Valley, Puebla, México. Journal of Arid Environment 67: 208-225. Doi: 10.1016/j.jaridenv.2006.02.013

Rzedowski, J., 1978. Vegetación de México. Limusa, Mexico, D.F.

Sandoval-Pérez, A.L., S.L. Camargo-Ricalde, N.M. Montaño, F. García-Oliva, A. Alarcón, S.A. Montaño-Arias, M. Esperón-Rodríguez, 2016. Biocrusts, inside and outside resource islands of Mimosa luisana (Leguminosae), improve soil carbon and nitrogen dynamics in a Mexican semiarid ecosystem. European Journal of Soil Biology 74: 93-103. Doi: 10.1016/j.ejsobi.2016.03.006

Selvakumar, G., K. Kim, D. Walitang, M. Chanratana, Y. Kang, B. Chung, T. Sa, 2016. Trap culture technique for propagation of arbuscular mycorrhizal fungi using different host plants. Korean Journal of Soil Science and Fertilizer 49: 608-613. Doi: 10.7745/ KJSSF.2016.49.5.608

Smith, S.E., D.J. Read, 2008. Mycorrhizal symbiosis. Academic Press, San Diego.

Sokal, R., F. Rohlf, 1995. Biometry. Freeman and Company, San Francisco.

Sorbitrán, L., M. Verdú, A. Valiente-Banuet, 2019. A nurse plant benefits from facilitative interactions through mycorrhizae. Plant Biology 21(4): 670-676. Doi: 10.1111/plb.12948

Statsoft, INC., 2000. Statistica for Windows vers. 6. Tulsa. OK, Tulsa. Stutz, J.C., J.B. Morton, 1996. Successive pot cultures reveal high species richness of arbuscular endomycorrhizal fungi in arid ecosystems. Canadian Journal of Botany 74: 1883-1889. Doi: 10.1139/b96-225

Tarafdar, J.C., J. Panwar, 2008. Role of arbuscular mycorrhizae in $P$ nutrition of plants under arid and semiarid environments. In: Montaño, N.M., S.L. Camargo-Ricalde, R. García-Sánchez, A. Monroy-Ata (eds.), Arbuscular mycorrhizae in arid and semiarid ecosystems. Mundi-Prensa, INE, UAM-Iztapalapa, FES-Zaragoza-UNAM, Mexico D.F. Pp. 41-53.

Toledo, V.M., M.J. Ordóñez, 1998. El panorama de la biodiversidad de México: una revisión de los hábitats terrestres. In: Ramamoorthy, T.P., R. Bye, A. Lot, J. Fa (eds.), Diversidad biológica de México: orígenes y distribución. Instituto de Biología, UNAM, Mexico, D.F. Pp. 739-757.

Uhlmann, E., C. Görke, A. Petersen, F. Oberwinkler, 2004. Arbuscular mycorrhizae from semiarid regions of Namibia. Canadian Journal of Botany 82: 645-653. Doi: 10.1139/b04-039

Uhlmann, E., C. Görke, A. Petersen, F. Oberwinkler, 2006. Arbuscular mycorrhizae from arid parts of Namibia. Journal of Arid Environment 64: 221-237. Doi: 10.1016/j.jaridenv.2005.05.002

Valiente-Banuet, A., E. Ezcurra, 1991. Shade as a cause of the association between the cactus Neobuxbaumia tetetzo and the nurse plant Mimosa luisana in the Tehuacán Valley. México. Journal of Ecology 79: 961-971. Doi: 10.2307/2261091

Valiente-Banuet, L., 1991. Patrones de precipitación en el Valle semiárido de Tehuacán, Puebla, México. B.Sc. Thesis. Facultad de Ciencias, UNAM, México.

Varela, L., L.V. Hernández-Cuevas, E. Chimal-Sánchez, N.M. Montaño, 2019. Diversidad taxonómica de hongos micorrizógenos arbusculares citados en México. In: Álvarez-Sánchez, J., P. Rodríguez-Guzmán, A. Alarcón (eds.), Biodiversidad de microorganismos de México: importancia, aplicación y conservación. 1a. ed. electrónica. UNAM, Ciudad de México. Pp. 104-155.

von Ende, C.N., 2001. Repeated measures analysis: growth and other time-dependent measures. In: Scheiner, S.M., J. Gurevitch (eds.), Design and analysis of ecological experiments. Champan and Hall, New York. Pp.113-137.

WRB, 2014. International soil classification system for naming soils and creating legends for soil maps. World Soil Resources Reports No. 106. FAO, Rome.

Zhang, Y., L.D. Guo, 2007. Arbuscular mycorrhizal structure and fungi associated with mosses. Mycorrhiza 17: 319-325. Doi: 10.1007/ s00572-007-0107-8 